\title{
GAMBARAN SISTEM PENDIDIKAN ISLAM PADA MASA SAHABAT
}

\author{
*Nurul Fajriah \\ *Nurul Fajriah adalah Widyaiswara Balai Diklat Keagamaan Aceh \\ Email:noeroelfajriah@gmail.com
}

\begin{abstract}
Abstrak
Tulisan ini adalah kajian literatur untuk mendeskripsikan pendidikan Islam pada masa sahabat khususnya pada masa sahabat besar diawali pada masa Abu Bakar as-Shiddiq, Umar bin Khatab, Usman bin Affan dan Ali bin Abi Thalib. Pendidikan Islam pada masa klasik dimulai sejak turunnya wahyu pertama dan Nabi Muhammad menjadi guru besar dalam dua periode yaitu periode Makkah dan periode Madinah. Fokus pendidikan Islam periode Makkah adalah pengenalan dan pendalaman aqidah tauhid sedangkan pada periode Madinah difokuskan pada pembinaan dasar-dasar hukum Islam dan mu'amalah. Pada masa sahabat besar yang berlangsung sekitar 30 tahun, wilayah Islam telah meluas dan materi pelajaran yang diajarkan pun berbeda dengan masa Nabi. pendidikan Islam sudah berkembang dengan munculnya ilmu-ilmu bahasa dan filsafat dengan tujuan melanjutkan dan mempertahankan apa yang sudah dicapai pada masa Nabi dan mewariskan nilai dan budaya Islami kepada generasi selanjutnya. Pada masa ini lembaga pendidikan formal seperti kuttab sudah berkembang ke seluruh wilayah Islam.
\end{abstract}

\section{Kata kunci: Sistem Pendidikan Islam, Masa Sahabat.}

\section{PENDAHULUAN}

Pendidikan Islam berdasarkan konsep qur'ani terjadi sejak masa Nabi Muhammad diangkat menjadi Rasul. Nabi Muhammad adalah guru dan teladan utama dalam penerapan sistem pendidikan Islam. Pendidikan pada masa ini merupakan prototype yang terus menerus dikembangkan oleh umat Islam untuk kepentingan pendidikan pada masa selanjutnya. Pendidikan Islam mempunyai sejarah panjang, yang dikembangkan seiring dengan kemunculan Islam itu sendiri. (Azra, 1999).

Dalam periode awal, pendidikan Islam dilaksanakan oleh Nabi Muhammad saw sebagai upaya pembebasan manusia dari belenggu aqidah yang sesat dan segala bentuk penindasan suatu kelompok terhadap kelompok lain yang dipandang rendah status sosialnya. Ajaran tauhid menjadi landasan kokoh dalam pembinaan dan pendidikan awal saat itu.

Prioritas pendidikan dalam bentuk penanaman dan penumbuhan tauhid dilaksanakan selama 10 tahun pada periode Makkah. Pembinaan dan pendidikan umat Islam dalam kehidupan sosial dan praktik ibadah difokuskan pada periode Madinah 
selama 13 tahun lebih (Nata, 2004: 30).

Setelah Rasulullah wafat, khulafa al-rasyidin menggantikan kedudukan beliau sebagai kepala pemerintahan dan tugas-tugas beliau yang lain kecuali tugas kenabian. Saat itu, wilayah Islam telah meliputi sebagian besar jazirah Arab. Dinamika pendidikan Islam masa sahabat menjadi semakin komplek seiring dengan berkembangnya Islam ke luar jazirah Arab (Syalabi, 2000: 226). Tulisan ini difokuskan untuk mendeskripsikan pendidikan Islam pada masa sahabat khususnya pada masa khulafa al-rasyidin dari tahun 11-40 H (631-661 M).

\section{METODE PENELITIAN}

Penelitian kepustakaan memiliki beberapa ciri khusus, antara lain; pertama penelitian ini berhadapan langsung dengan teks atau data angka, bukan dengan lapangan atau saksi mata (eyewitness), berupa kejadian, orang atau benda-benda lain. Kedua, data bersifat siap pakai (readymade), artinya peneliti tidak pergi kemana-mana, kecuali hanya berhadapan langsung dengan sumber yang sudah ada di perpustakaan. Ketiga, data diperpustakaan umumnya adalah sumber data sekunder, dalam arti bahwa peneliti memperoleh data dari tangan kedua bukan asli dari tangan pertama dilapangan. Keempat, kondisi data di perpustakaan tidak dibagi oleh ruang dan waktu (Mestika Zed, 2004).

Tulisan ini adalah kajian literatur tentang pendidikan Islam pada masa sahabat. Sumber kajian adalah berupa buku-buku yang berkenaan dengan sejarah pendidikan Islam dan Jurnal-jurnal ilmiah yang relevan. Di antaranya adalah Mahmud Yunus. 1989. Sejarah Pendidikan Islam. Jakarta: Hidayakarya Agung dan Hanum Asrohah. 1999. Sejarah Pendidikan Islam, Jakarta: Logos.

Pembahasan dilakukan berdasarkan metode analisis tematik (thematic Analysis). Menurut Arnold (2006) analisis tematik adalah metode untuk mengidentifikasi, menganalisis dan melaporkan pola-pola atau tema dalam suatu data. Oleh karena itu metode ini dapat mengatur dan menggambarkan data secara mendetail agar dapat menafsirkan berbagai aspek tentang topik penelitian.

\section{HASIL PENELITIAN}

\section{Konsep Pendidikan Islam Pada Masa Sahabat}


Pendidikan Islam pada masa Rasul menghasilkan budaya Islami yang lengkap dan sempurna dengan nilai-nilai transendental yang terkandung di dalamnya. Budaya dan nilai tersebut dapat diterapkan pada setiap zaman. Budaya dan nilai tersebut menghasilkan sebuah sistem pendidikan yang diwariskan pada generasi berikutnya untuk dikembangkan, sesuai dengan laju peradabannya. Pengembangan sistem pendidikan secara kualitatif, berarti budaya dan nilai yang terkandung di dalam kegiatan pendidikan dapat terus berubah menuju kepada kesempurnaan sesuai tuntunan syariat.

Pengembangan sistem pendidikan secara kuantitatif, mengarah pada penyempurnaan pemahaman terhadap ajaran dan budaya bagi kesejahteraan hidup manusia. Sumber pengembangan ajaran dan budaya tersebut adalah wahyu Allah dan sunnah dari rasulullah.

Pendidikan Islam pada masa sahabat dan masa-masa berikutnya berorientasi pada dua sasaran, yaitu generasi muda dan dakwah. Generasi muda adalah generasi penerus, Sedangkan dakwah berarti penyampaian ajaran Islam dan usaha menginternalisasikan nilai-nilai Islami dalam masyarakat bangsa yang baru menerimanya.

\section{Masa Abu Bakar ash-Shiddiq (11-13 H/631-634 M)}

Khalifah Abu Bakar ash-Shiddiq terpilih secara aklamasi pada peristiwa Saqifah Bani Sa'idah pada saat jenazah Rasulullah Saw., belum lagi dimakamkan. Abu Bakar adalah khalifah Islam pertama yang dilantik oleh seluruh komunitas muslim sepeninggal Nabi Muhammad. Ia berasal dari kalangan bangsawan Makkah yang kaya raya dan sebagai orang kedua yang memeluk Islam setelah Khadijah. Ia merupakan sahabat terdekat Nabi Muhammad yang kesetiaannya tidak pernah berkurang sedikitpun dan Seluruh hidupnya dicurahkan untuk perjuangan suci membela dakwah Islam. ia dikenal dengan gelar al-shiddiq (penuh kepercayaan). ia menggantikan Nabi Muhammad sebagai Imam shalat ketika Nabi sedang sakit. Selama masa-masa awal perjuangan Islam, Abu bakar menggunakan harta kekayaannya untuk mengatasi kesulitan ekonomi masyarakat muslim dan membebaskan sejumlah budak yang disiksa tuannya lantaran keimanan mereka terhadap Islam. Di antara budak yang dibelinya untuk dimerdekakan adalah Bilal (Glasse, 2002). 


\section{Nurul F ajriah, G ambaran Sistem Pendidikan Islam}

Lebih lanjut Glasse (2002) menjelaskan, jauh sebelum memeluk Islam, Abu Bakar dihormati di kalangan suku Quraisy Makkah karenanya sifatnya yang pemurah dan peramah. Nama Aslinya Abdullah ibn Abi Quhafah. Abu Bakar (“Ayah dari seorang gadis") merupakan nama samaran, nama kebapakan, yang secara tidak langsung menunjukkan penghormatan kepadanya. Ia disebut dalam al-Qur'an sebagai satu di antara orang yang bersembunyi di dalam gua Tsur, ketika menemani Nabi bersembunyi dari kejaran kafir Makkah dalam perjalanan hijrah ke Madinah.

Setelah Nabi Muhammad wafat, berdasarkan hasil musyawarah kaum muslimin Abu Bakar di bai'at menjadi khalifah. Khalifah adalah pemimpin yang diangkat sesudah Nabi Muhammad wafat untuk menggantikan beliau melanjutkan tugas-tugas sebagai pemimpin agama dan kepala pemerintahan

Sejarah penting setelah Nabi Muhammad wafat adalah peristiwa pemberontakan dari orang-orang murtad yang enggan membayar zakat, serta timbulnya nabi-nabi palsu pada awal kekhalifahan Abu Bakar. Para pemberontak tersebut adalah dari kalangan orang yang baru memeluk Islam, dengan sendirinya mereka belum mantap keislamannya. Mereka masih perlu bimbingan lebih lanjut dalam melaksanakan ajaran-ajaran Islam.

Untuk mengatasi pemberontakan tersebut Abu Bakar mengirim pasukan yang terdiri dari para sahabat. Tetapi karena mereka tetap membangkang terjadilah pertempuran yang cukup hebat, sehingga banyak di antara para sahabat yang mati syahid, yang menyebabkan berkurangnya penghafal-penghafal al-Qur'an, guru dan pendidik Islam. Problema ini mula-mula disadari oleh Umar bin Khatab sebelum ia menjadi khalifah. Maka para sahabat pun bermusyawarah dibawah pimpinan khalifah Abu Bakar untuk mengatasi masalah tersebut.

Untuk mengatasi agar al-Qur'an jangan sampai hilang, maka penulisan alQur'an yang pada zaman Nabi Muhammad masih belum tersusun sesuai hafalan para sahabat, dituliskan kembali dan dijadikan satu mushaf. Para sahabat dikirim keberbagai daerah yang dikuasai kaum muslimin untuk mengajarkan al-Qur'an dan memasukkan ajaran-ajaran Islam ke dalam budaya penduduk daerah-daerah baru tersebut. Timbullah pusat-pusat pendidikan Islam yang tersebut diseluruh daerah yang dikuasai kaum muslimin (Zuhairini, 1997: 71). Masa Abu Bakar merupakan masa awal pengumpulan al-qur'an. Pada masa ini kumpulan al-qur'an ditulis pada tulang- 
tulang dan pelepah kurma, di kumpulkan pada salah seorang istri Rasulullah Hafsah binti Umar bin Khatab.

Mahmud Yunus dalam bukunya Sejarah Pendidikan Islam, lebih lanjut menjelaskan, materi pendidikan Islam pada masa ini terdiri dari pendidikan tauhid atau keimanan, akhlak, ibadah, kesehatan.

1. Pendidikan keimanan, yaitu menanamkan bahwa satu-satunya yang wajib disembah adalah Allah.

2. Pendidikan akhlak, seperti adab masuk rumah orang, sopan santun bertetangga, bergaul dalam masyarakat, dan lain sebagainya. Pendidikan ibadah seperti pelaksanaan shalat, puasa dan haji.

3. Kesehatan seperti tentang kebersihan, gerak gerik dalam shalat merupakan didikan untuk memperkuat jasmani dan rohani

Pada masa Abu bakar dapat disimpulkan bahwa pendidikan pada masa itu hanya melanjutkan pendidikan yang sudah ada pada zaman Rasulullah, pendidikan pada masa ini belum mengalami perkembangan yang begitu berarti karena Abu Bakar banyak disibukkan oleh keadaan pemerintahan yang kurang kondusif yang perlu perhatian penuh.

\section{Masa Umar bin Khatab (13-23 H/ 634 M - 644 M)}

Umar bin Khatab lahir pada tahun 513 M pada sebuah keluarga suku Quraisy. Ia semula dipanggil dengan gelar Abu Hafs. Setelah memeluk Islam menerima gelar alfaruq. Pada masa mudanya umar adalah seorang pegulat dan orator ulung. Ia merupakan satu-satunya sahabat yang telah mengenal baca tulis. Berdagang adalah usahanya yang paling utama (Ali, 2003: 150).

Umar merupakan satu diantara tokoh-tokoh besar dalam sejarah Islam. Ia terkenal dengan tekad dan kehendaknya yang sangat kuat, cekatan, dan karakternya yang berterus terang, bebelum menjadi khalifah dikenal sebagai pribadi yang keras dan tidak mengenal kompromi dan bahkan kejam. Di bawah pemerintahannya imperium Islam meluas dengan kecepatan yang luar biasa. Dapat dikatakan bahwa orang yang terbesar pengaruhnya setelah Nabi dalam membentuk pemerintahan Islam dan menegaskan coraknya adalah Umar bin Khattab (Glasse, 2002). 


\section{Nurul F ajriah, Gambaran Sistem Pendidikan Islam}

Pada masa pemerintahan Umar kondisi negara sudah agak stabil, jadi Umar dapat memusatkan perhatiannya dalam masalah-masalah kenegaraan yang lain termasuk pendidikan. Berkaitan dengan masalah pendidikan, khalifah Umar ibnu Khatab merupakan seorang pendidik yang melakukan penyuluhan pendidikan di kota Madinah, beliau juga menerapkan pendidikan di masjid-masjid dan pasar pasar, serta mengangkat guru-guru untuk tiap-tiap daerah yang ditaklukkan. Mereka bertugas mengajarkan isi Alquran, fiqih, dan ajaran Islam lainnya kepada penduduk yang baru masuk Islam (Nizar, 2009).

Pada masanya Umar sangat memperhatikan masalah pendidikan dan menambah materi pelajaran. Pada masa Umar kaum muslimin sudah mulai mempelajari bahasa-bahasa Asing seperti bahasa Persia, Romawi, dan bahasa lain yang dianggap perlu waktu itu, karena pengajaran bahasa asing pada waktu itu menjadi hal yang sangat dipentingkan mengingat daerah kekuasaan Islam sudah berada di luar jazirah Arab. Jadi dapat disimpulkan bahwa suhu politik negara pada waktu itu cukup stabil, kondisi ini memberikan dampak positif bagi perkembangan pendidikan Islam pada masa ini.

\section{Masa Usman bin Affan ( 23-35 H / 644-656 M)}

Usman dilahirkan pada tahun 573 M, berasal dari keluarga suku Quraisy pada klan Bani Umayyah. Moyangnya bersatu dengan nasab Nabi Muhammad pada generasi kelima. Sebelum memeluk Islam ia dipanggil dengan nama “Abu Amar”. Ia bergelar dzu al-nurain, karena ia menikahi dua puteri Nabi. Ayahnya bernama Affan dan ibunya bernama Arwa. Ia adalah sahabat Nabi yang pandai membaca dan menulis, semenjak kecil dikenal sebagai orang yang cerdas dan jujur (Ali, 2003: 177).

Pada masa Khalifah Usman bin Affan, pelaksanaan pendidikan Islam tidak jauh berbeda dengan masa-masa sebelumnya. Pendidikan pada masa ini hanya melanjutkan apa yang telah ada. Hanya sedikit perubahan yang mewarnai pelaksanaan pendidikan Islam dari apa yang telah ada. Para sahabat besar Rasulullah Saw., yang berpengaruh dan dekat dengan Rasulullah Saw., pada masa Khalifah Umar tidak diizinkan meninggalkan Madinah, maka pada masa Khalifah Usman diberikan sedikit kelonggaran untuk keluar Madinah dan menetap di daerah-daerah yang mereka sukai. Di daerah-daerah yang baru tersebut mereka 
mengajarkan ilmu-ilmu keislaman yang mereka miliki dan dapatkan langsung dari Rasulullah Saw. Kebijakan ini besar sekali manfaatnya bagi pelaksanaan pendidikan Islam di daerah-daerah yang baru. Sebelumnya umat Islam di luar Madinah dan Mekkah, khususnya dari luar Semenanjung Arabia, harus menempuh perjalanan yang jauh, melelahkan dan memakan waktu yang lama untuk bisa menuntut ilmu- ilmu agama Islam di Madinah. Tetapi dengan tersebarnya para sahabat Rasulullah Saw., yang langsung mendapatkan pengajaran dari Nabi ke berbagai daerah meringankan umat Islam di daerah-daerah yang baru untuk belajar ilmu-ilmu agama Islam kepada para sahabat Nabi yang mempunyai pengetahuan yang banyak dalam ilmu-ilmu agama Islam di daerah mereka sendiri atau di daerah yang terdekat (Niswah, 2015: 178).

Jasa besar khalifah Usman bin Affan dalam sejarah pendidikan Islam yaitu membukukan al-qur'an dan menyatukan bacaan al-Quran umat Islam yang berbeda satu sama lain karena bertambahnya daerah kekuasaan Islam sehingga menyebabkan umat Islam berlainan dialek dalam membaca al-Qur'an yang terkenal dengan mushaf Utsmani, tapi pemikiran kreatif tidak muncul pada waktu itu. Justru kelemahlembutannya pada waktu itu dipergunakan oleh keluarga Bani Umayyah yang pernah memegang kekuasaan politik sebelum Islam untuk meningkatkan dan mengembalikan kedudukannya sebagai pemimpin Quraisy pada masa silam. Karena peluang yang dimanfaatkan oleh keluarga Umayyah untuk menduduki jabatan penting menyebabkan timbulnya protes dan sikap oposisi yang datang hampir dari selurh daerah. Gerakan itu berakhir dengan terbunuhnya khalifah ketiga, Usman bin Affan (Zuhairini, 1997: 32). Masa ini dianggap sebagai awal sejarah timbulnya perpecahan dalam kalangan umat Islam.

Pendidikan Islam pada masa khalifah Usman bin Affan statis dan tidak mengalami perkembangan yang berarti, karena Usman banyak disibukkan oleh hal-hal lain yang dianggap jauh lebih penting.

\section{Masa Ali bin Abi Thalib ( 35-40 H / 656-661 M)}

Ali adalah putra Abu Thalib, seorang paman yang mengasuh Nabi semenjak sang kakek meninggal dunia. Ali tergolong pada keturunan keluarga Hasyimiyah, sama dengan keturunan Nabi Muhammad. Garis keturunan inilah yang menduduki kekuasaan tertinggi atas ka'bah dan sekitarnya sebelum Nabi lahir. Ali lahir pada 
tahun kesepuluh sebelum tahun kerasulan Muhammad. Semenjak kecil ia selalu bersama Nabi, sehingga masa kecil Ali tumbuh dalam pengasuhan dan bimbingan Nabi. Nabi menyayanginya seperti anak sendiri dan menikahkannya dengan Fatimah putrinya pada tahun kedua hijrah (Ali, 2003: 201).

Pada masa khalifah Ali bin Abi Thalib ibu kota pemerintahan dipindah ke Kufah. Pada masa itu khalifah Ali bin Abi Thalib mengurus masalah politik dan pemerintahan, sedangkan Abdullah bin Mas'ud mengurus masalah pendidikan agama Islam. Selama masa pemerintahannya yang berlangsung selama lebih kurang lima tahun khalifah Ali disibukkan oleh banyaknya peperangan yang dilancarkan oleh kelompok Bani Umayyah yang mendesaknya untuk mengusut kasus pembunuhan Usman (Langgulung, 1995).

Gejolak politik yang terjadi pada masa itu, mempengaruhi perkembangan pendidikan. Ciri khas pendidikan Islam pada masa ini ditunjukkan dengan: 1. Menonjolkan unsur Arab pada pendidikan Islam, 2. Bertujuan menegakkan prinsip agama Islam. Pendidikan Islam berkembang dengan metode dakwah, 3. Bergantung penuh pada ilmu-ilmu al-qur'an dan al-Hadits (naqliyah). Pada masa ini muncul berbagai ilmu agama seperti tafsir, hadits, tajwid, fiqih. Demikian juga dengan ilmuilmu yang berkaitan dengan ilmu-ilmu bahasa, nahwu, sastra, balaghah dan lain-lain, 4. Mementingkan penulisan sebagai alat penghubung antara sanad dengan kaum muslimin. Sanad adalah guru dari kalangan sahabat, 5. Membuka pintu lebar-lebar untuk mempelajari bahasa asing. Ini didorong oleh keperluan bertambahnya kawasan Islam yang mendorong orang Islam menguasai bahasa asing, 6. Bergantung penuh pada surau (kuttab) dan mesjid sebagai pusat-pusat pendidikan, atau sekarang disebut institusi pendidikan.

\section{Sistem Pendidikan Islam Pada Masa Sahabat}

Sistem pendidikan adalah serangkaian unsur-unsur yang terkait dengan komponen pendidikan yaitu pendidik, subjek didik, tujuan pendidikan, metode pendidikan, sarana dan prasarana pendidikan, dan lain sebagainya.

\section{Pendidik}

Pada masa klasik sahabat memegang peranan yang sangat penting dalam proses pendidikan, mulai dari perencanaan sampai melaksanakannya. Pada masa ini, 
pendekatan yang digunakan dalam kegiatan pendidikan adalah teacher centered atau teacher oriented. Guru pada masa ini secara teratur sudah melaksanakan tugas dan mewariskan ilmunya secara sungguh-sungguh. Para guru selalu memperlakukan murid secara adil tanpa ada diskriminasi (Nata, 2004: 150).

Kegiatan pembelajaran pada masa ini sangat tergantung pada guru (teacher centered atau teacher oriented ), syarat menjadi guru pada waktu itu adalah memiliki pemahaman agama yang tinggi. Sebagian guru-guru tersebut adalah alumni lembaga pendidikan pertama di bawah kepemimpinan Rasulullah. Pada waktu itu ajaran Islam juga diajarkan kepada orang yang baru masuk Islam, sehingga banyak timbul pertanyaan-pertanyaan mengenai masalah-masalah yang berhubungan dengan Islam. Guru pada masa tersebut sangat berperan aktif dalam mengajar, dan muridnya mendengar dengan baik penjelasan guru.

Dalam periode Rasulullah dan sahabat pendidikan Islam mulai berkembang. Pada saat inilah lahir guru-guru hebat karena keluasan ilmu mereka. Diantaranya adalah Ali ibn Abi Thalib, Umar ibn Khatab, Anas bin Malik, Muaz bin Jabal, Abu Hurairah, Abdullah bin Mas'ud, Abdullah bin Abbas, Abdullah bin Umar, Abdullah bin Amr bin Ash, Zaid bin Sabit, Abu Darda, Abu Said al-Khudri, Abu Musa alAsy'ari, Aisyah r.a. dan sahabat-sahabat lain yang mencapai tahap tinggi sekali dalam ilmu-ilmu syariat seperti tafsir, fiqh, qada, faraidh, dan hadits.

Berdasarkan uraian di atas dapat dipahami bahwa para pendidik pada periode sahabat adalah khalifah yang empat, Aisyah dan para sahabat yang langsung mendapatkan ilmu dari Rasulullah.

\section{Peserta Didik}

Peserta didik merupakan salah satu dari komponen pendidikan yang berpengaruh terhadap pencapaian tujuan pendidikan. Tanpa peserta didik, pengajaran tidak akan ada dan tidak akan terjadi.

Di awal perkembangan Islam, para penuntut ilmu tidak ada perbedaan. Ketika Rasulullah masih hidup, semua sahabat diberi kesempatan yang sama untuk mendapatkan pengetahuan dan pengalaman tentang ajaran Islam dari Rasulullah Saw. Dalam kenyataannya, tidak semua sahabat dapat memanfaatkan kesempatan untuk 


\section{Nurul F ajriah, Gambaran Sistem Pendidikan Islam}

menimba ilmu dari beliau. Hal ini bisa dipahami karena para sahabat mempunyai pekerjaan dan aktivitas yang berbeda (Abuddin Nata, 2004: 130).

Peserta didik pada masa sahabat ini terdiri dari laki-laki dan perempuan. Dalam hal ini tidak ada perbedaan antara laki-laki dan perempuan dalam menuntut ilmu sebagaimana hadis Rasulullah menuntut ilmu hukumnya wajib bagi setiap orang Islam laki-laki dan perempuan.

\section{Tujuan Pendidikan}

Pendidikan Islam yang dilakukan Nabi di Mekkah merupakan prototype yang bertujuan untuk membina masyarakat muslim, agar menjadi generasi yang berjiwa kuat. Mereka dipersiapkan sebagai kader, muballigh dan pendidik yang baik bagi seluruh manusia. Dalam periode Madinah, pendidikan Islam mengalami perkembangan yang pesat, selain bertujuan membentuk kader muballigh juga diarahkan untuk membina aspek-aspek kemanusiaan dalam mengelola dan menjaga kesejahteraan alam semesta.

Adapun tujuan pendidikan Islam yang dilakukan pada masa sahabat adalah melanjutkan dan mempertahankan apa yang sudah dicapai pada masa Nabi. Pada masa ini pendidikan Islam merupakan upaya untuk mewariskan nilai dan budaya Islami kepada generasi selanjutnya (Abuddin Nata, 2004). Generasi selanjutnya yang dimaksudkan adalah era thabi'in dan thabi' thabi'in yang mampu mengembangkan peradaban Islam sampai menuju puncak peradaban.

\section{Metode Pendidikan}

Dalam proses belajar mengajar, metode pendidikan merupakan salah satu aspek pendidikan yang sangat penting. Metode pendidikan sangat menetukan keberhasilan seorang pendidik dalam mentransfer pengetahuan dan kebudayaan kepada muridnya.

Dalam pendidikan nilai, metode yang tepat akan menyebabkan internalisasi nilai dapat diterima dengan baik. Hal ini terbukti melalui kisah-kisah keteladanan nabi dan para sahabat. Metode ini dapat diartikan sebagai seni (art of teaching) yang meliputi gerak tubuh dalam berkata, berbuat dan diamnya seorang pendidik. Metode pendidikan Islam yang paling awal dilakukan adalah metode ceramah, metode diskusi, metode hafalan, metode baca tulis, metode dakwah individu baik secara sir 
dan jahr. Pada masa sahabat metode pendidikan Islam berkembang menjadi metode halaqah dan dakwah komunal.

\section{Kurikulum Pendidikan}

Pada masa sahabat, pakar pendidikan Islam menggunakan kata-kata al-maddah untuk pengertian kurikulum. Kurikulum lebih identik dengan serangkaian mata pelajaran yang diberikan kepada murid.

Tafsir (2005: 60), menjelaskan bahwa pada masa Nabi di Madinah kurikulum pendidikan terdiri atas: a. Membaca al-Qur'an, b. Keimanan (rukun iman), c. Ibadah (rukun Islam), d. Akhlak, e. Dasr Ekonomi, f. Dasar politik, g. Olah raga dan kesehatan (pendidikan jasmani), h. Membaca dan menulis

Dari keterangan di atas dapat disimpulkan bahwa kurikulum pada masa Nabi Muhammad secara keseluruhan telah mencakup aspek pembinaan jasmani, akal dan rohani (hati). Lebih lanjut Tafsir (2005: 60) menggambarkan bahwa pada masa sahabat. Abubakar dkk (2019: 126). Menyebutkan Islamic Shariah also includes education, and Islamic mission (da'wah Islamiyah), it means that the practices of education is integrated with the Islamic cultural context (artinya dalam dalam hukum Islam juga mengandung pendidikan.

khususnya pada masa khulafa al-rasyidin dan masa sesudahnya kurikulum itu telah bertambah. Secara ringkas kurikulum pendidikan Islam pada masa ini ialah sebagai berikut: 1. Membaca dan menulis, 2. Membaca al-Qur'an dan menghafalkannya, 3. Keimanan, ibadah dan akhlak, 4. Pada masa kekhalifahan Umar bin Khatab menginstruksikan kepada penduduk kota supaya anak-anak diajarkan, 5. Berenang, 6. Menunggang kuda, 7. Memanah, 8. Membaca dan menghafal syair yang mudah dan peribahasa

Di sekolah tingkat menengah dan tinggi, pengajaran terdiri dari: 1. Al-Qur'an dan tafsirnya, 2. Hadis dan pengumpulannya, 3. Fikih. Sepanjang sejarah Islam khususnya pada masa pertumbuhan dan perkembangan Islam, lembaga-lembaga pendidikan Islam tidak mengembangkan tradisi keilmuan, khususnya ilmu-ilmu alam dan eksakta. Akan tetapi hanya ilmu agama (ulum al-diniyyah) yang menjadi titik sentral pembahasan. Walaupun pada dasarnya Islam sendiri tidak membedakan nilai 
ilmu agama dan agama, tapi pada praktiknya supremasi keilmuan masih diberikan kepada ilmu-ilmu agama.

\section{Lembaga Pendidikan}

Adapun lembaga-lembaga pendidikan pada masa nabi dan masa sahabat sama yaitu:

a) Shuffah

Pada masa Rasulullah shuffah adalah suatu tempat yang dipakai untuk aktifitas pendidikan, demikian juga pada masa berikutnya. Biasanya tempat ini menyediakan pemondokan bagi pendatang baru dan orang-orang yang tergolong miskin. Di sini para murid diajarkan untuk membaca dan menghafal al-qur'an secara benar. Mereka juga diajarkan Islam di bawah bimbingan langsung dari Nabi. Rasulullah mengangkat Ubaid bin al-Samit sebagi guru pada sekolah shuffah di Madinah. Dalam perkembangan selanjutnya shuffah juga menawarkan pelajaran dasar berhitung, kedokteran, astronomi, genelogi, dan ilmu fonetik.

Bidang-bidang studi yang diajarkan di Shuffah adalah al-qur'an, tajwid, dan semua ilmu-ilmu keIslaman di samping membaca dan menulis. Keberlangsungan alShuffah ini sangat diperhatikan oleh khulafa al-Rasyidin Umar bin Khatab misalnya, sentiasa mengangkat sahabat Rasul yang memilki pengetahuan agama yang luas sebagai panglima dan gubernur. Mereka banyak mendirikan mesjid dengan al-Shuffah di dalamnya. Kegiatan pendidikan ini kemudian dibantu pembiayaannya dengan dana pemerintah yang tersedia (Sukarno dan Ahmad Supardi, 1985: 51)

Pada masa sahabat, para guru atau pendidik yang mengajar di al-Shuffah ini adalah alumni dari lembaga al-Shuffah pertama di bawah bimbingan Nabi seperti Abu Hurairah, Abdullah bin Umar, dan lain sebagainya.

b) Kuttab / maktab

Maktab atau kuttab adalah adalah lembaga pendidikan Islam tingkat dasar yang mengajarkan membaca dan menulis kemudian meningkat pada pembelajaran alqur'an dan pengetahuan agama tingkat dasar. Lembaga ini telah dikenal masyarakat Arab pra-Islam sebagai lembaga tempat mengajarkan pengetahuan dan keterampilan membaca dan menulis. Pada zaman Nabi, kuttab mulai dikenal pasca terjadinya 
perang Badar. ketika terjadi perang Badar, ada beberapa musuh Islam yang tertawan. Tawanan yang bisa baca tulis dapat menebus dirinya dengan mengajarkan baca-tulis kepada 10 orang anak Madinah, setelah 10 orang anak-anak pandai baca tulis, tawanan itu bebas dan boleh kembali ke negerinya (Tafsir, 2005: 59). Itulah cara Nabi Nabi Mengajarkan baca tulis untuk memberantas buta huruf.

Menurut Armai Arief (2014: 143), kurikulum kuttab pada zaman klasik menunjukkan hal-hal sebagai berikut:

1) Walaupun kuttab sudah ada sejak pra-Islam dan tujuan pertamanya untuk belajar baca tulis, tapi kemudian pelajaran Al-Qur'an menjadi tema penting pelajaran di kuttab. Tentu dengan pelajaran al-Qur'an ini tidak sekedar memenuhi aspek kognitif saja, tetapi dimaksudkan untuk memenuhi aspek apektif, sehingga anak dapat mengapresiasi nilai-nilai al-Qur'an.

2) Masalah pendidikan akhlak amat diperhatikan, sebab hal ini merupakan aktualisasi dari pesan al-Qur'an. Lembaga pendidikan masa itu berarti lembaga pengawal moral. Pelanggaran moral merupakan pelanggaran berat, sehingga biasanya seluruh pelajaran- terutama pelajaran agama, selalu mengandung muatan moral.

3) Pelajaran seni, seperti seni tari dan seni musik tidak dikembangkan di kuttab. Mungkin seni-seni yang seperti ini dikhawatirkan dapat merusak akhlak anak.

4) Pelajaran-pelajaran lain di luar pelajaran al-Qur'an seperti tata bahasa Arab mungkin diberikan sebagai media untuk memahami al-Qur'an

5) Pelajaran olah raga dan berhitung belum mendapat keterangan yang rinci bagaimana materi dan pelaksanaannya di kuttab-kuttab.

6) Tidak terlihat adanya pelajaran yang benar-benar dapat dijadikan basis pengembangan sains pada jenjang pendidikan berikutnya.

Selanjutnya Tafsir (2005: 61), menerangkan bahwa sesudah masa sahabat, mata pelajaran yang diajarkan di kuttab semakin bervariasi, diantaranya adalah: 1. Membaca alQur'an dan menghafalnya, 2. Pokok-pokok agama: iman, ibadah, akhlak, 3. Membaca dan menulis, 4. Kisah tokoh-tokoh Islam, 5. Membaca dan menghafal syair atau natsar (prosa), 6. Berhitung, 7. Pokok-pokok nahwu dan sharaf 


\section{Nurul F ajriah, Gambaran Sistem Pendidikan Islam}

c) Halaqah

Halaqah artinya lingkaran. Artinya, proses belajar mengajar di sini dilaksanakan di mana murid-murid melingkari gurunya. Seorang guru biasanya duduk di lantai menerangkan. Kegiatan halaqah ini biasanya terjadi di masjid atau di rumah-rumah (Asrohah, 1999: 49).

Lingkaran (halaqah) adalah bentuk tertua dari pengajaran Islam, sejak masa Nabi Muhammad, yang berperan memimpin kegiatan bagi para pengikutnya baik pria maupun wanita. Dalam halaqah tradisional, guru duduk di atas bantal membelakangi dinding atau pilar. Para siswa duduk dalam setengah lingkaran di sekitar guru, sesuai peringkat pengetahuannya. Pada awal Islam, para guru di halaqah termasuk laki-laki dan perempuan. Situs pertama untuk kalangan belajar berada di masjid (masjid). Guru terkenal dikaitkan dengan kota dan masjid tertentu, dan biasanya juga untuk nama pilar bagi ulama terkenal yang duduk di sana. Lingkaran belajar juga diadakan di lembaga lain dan rumah. Siswa melakukan perjalanan untuk duduk dalam lingkaran seorang sarjana terkenal. Tradisi merekam pemaparan pengajar berkembang menjadi pengajaran yang lebih sistematis. Metode yang dilakukan para guru dalam mengampu mata pelajaran, memungkinkan siswa mereka untuk mengajukan pertanyaan dan menguji pengetahuan mereka. Kesuksesan belajar dihargai dengan surat, atau sertifikat belajar (ijazah). Tradisi halaqah formal dan informal berlanjut sampai hari ini dalam kebudayan Muslim (Nakosten, 1995: 60-61 dalam Fathurrahman, 2017: 62 ).

Dalam halaqah yang diselenggarakan di masjid siapapun bisa bergabung baik statusnya sebagai murid yang terdaftar ataupun sekedar pengunjung yang berminat mengikuti kajian. Mereka yang menjadi murid pada halaqah tersebut diberi tugas untuk melakukan pembacaan terhadap sumber-sumber keilmuan penunjang agar tidak mengalami kesulitan dalam memahami uraian mudarris ketika proses kajian berlangsung, juga dituntut untuk berkonsentrasi secara sungguh-sungguh. Kegiatan diskusi aktif pun diintensifkan untuk menggali lebih dalam untuk menangkap wawasan lebih luas tentang ajaran Islam.

Kurikulum di lembaga halaqah ini bervariasi tergantung pada guru yang mengajar artinya tidak ada kurikulum khusus. Para murid tidak terikat untuk mempelajari mata pelajaran tertentu, demikian juga guru juga tidak mewajibkan 
kepada murid untuk mengikuti kurikulum tertentu. Murid bebas mengikuti pelajaran di sebuah halaqah dan berpindah dari sebuah halaqah ke halaqah yang lain, bahkan dari satu kota ke kota.

Kegiatan di halaqah ini, tidak khusus atau mengajarkan ilmu agama, tetapi juga ilmu pegetahuan umum, termasuk filsafat karena pada masa ini Islam sudah melakukan kontak dengan dunia luar khususnya pada masa Umar bin Khatab, yang berhasil memperluas daerah kekuasaan Islam. Oleh karena itu, halaqah ini dikelompokkan ke dalam lembaga pendidikan yang terbuka terhadap ilmu pengetahuan umum.

d) Majlis

Istilah majlis telah dipakai dalam pendidikan sejak abad pertama Islam. Mulanya ia merujuk pada tempat arti tempat-tempat pelaksanaan belajar mengajar. Dalam majlis ini, murid yang belajar disini adalah orang dewasa, dan juga remaja. Mengenai materi yang dipelajari tetap berkisar dengan al-qur'an dan ilmu-ilmu agama.

e) Masjid

Semenjak berdirinya di zaman Nabi, mesjid telah menjadi pusat kegiatan dan informasi berbagai masalah kaum muslimin, baik yang menyangkut pendidikan maupun ekonomi. Namun, yang lebih penting adalah sebagai lembaga pendidikan. Sebagai lembaga pendidikan masjid pada awal perkembangannya dipakai sebagai sarana informasi dan penyampaian doktrin Islam.

Pada masa Nabi Muhammad Saw dan khalifah Abu Bakar Shiddiq masjid masih berfungsi sebagai tempat ibadah dan pendidikan Islam tanpa ada pemisahan yang jelas antara keduanya hingga masa Amirul Mukminin, Umar ibn Khattab. Pada masanya, di samping atau di beberapa sudut masjid dibangun kuttab-kuttab, untuk tempat belajar anak-anak. Sejak masa inilah pengaturan pendidikan anak-anak dimulai. Hari Jum'at adalah hari libur mingguan sebagai persiapan melaksanakan shalat Jum'at. Khalifah Umar ibn Khattab mengusulkan agar para pelajar diliburkan pada waktu dzuhur hari kamis, agar mereka bersiap-siap menghadapi hari Jum'at. Usul ini kemudian menjadi tradisi hingga sekarang (Arief, 2014: 41). 
Sebagai institusi pendidikan Islam periode awal, masjid menyelenggarakan kajian-kajian baik dalam bentuk diskusi, ceramah dan model pembelajaran yang memiliki bentuk atau format tersendiri. yang disesuaikan dengan tingkat perkembangan masyarakat muslim pada masa itu yang pada masa-masa berikutnya terus mengalami inovasi dan pembaruan. Hasil inovasi dan pembaruan tersebut sebagai konsekwensi dari tuntutan dan kebutuhan masyarakat muslim terhadap pendidikan Islam yang terus mengalami perubahan dan peningkatan.

\section{KESIMPULAN}

Pendidikan Islam pada masa Nabi yaitu periode Makkah menitikberatkan pada pendidikan tauhid (dalam arti yang luas), sedangkan pada periode Madinah, difokuskan pada pembinaan hukum Islam, mu'amalah dan pendidikan sosio politik. Pada kedua periode ini materi pendidikan hanya berkisar pada masalah ulum aldiniyyah. Pada masa sahabat khususnya pada masa khulafa al-rasyidin wilayah Islam telah meluas dan materi pelajaran yang diajarkan pun berbeda dengan masa Nabi. Pada masa ini selain ulum al-diniyyah juga sudah diajarkan ilmu-ilmu bahasa, bahasabahasa asing bahkan juga filsafat. Pada masa ini sudah ada semacam lembaga pendidikan formal yang tersebar diseluruh wilayah kekuasaan Islam.

\section{DAFTAR PUSTAKA}

- Ali, K. 2003. Sejarah Islam dari Awal Hingga Runtuhnya Dinasti Utsmani (Tarikh Pramodern). Jakarta: Raja Grafindo Persada

- Arief, Armai (ed). 2014. Sejarah Pertumbuhan Lembaga-Lembaga Pendidikan Islam Pada Masa Klasik. Bandung: Angkasa

- Mestika Zed, 2004. Metode Penelitian Kepustakaan (Jakarta: Yayasan Obor Indonesia

- Azra, Azyumardi. 1999. Pendidikan Islam: Tradisi dan Modernisasi Menuju Milenium Baru, Jakarta: Logos.

- Asrohah, Hanum. 1999. Sejarah Pendidikan Islam, Jakarta: Logos

- Fathurrahman. 2017. Eksistensi Kuttab dan Masjid sebagai Institusi Pendidikan pada Masa Pertumbuhan Islam. Jurnah Ilmiah Kreatif. Vol. XIV No. 1. 
- Abubakar, A., Srimulyani, E. and Anwar, A., 2019. Identification of Some Distinctive Values of Acehnese Malee (Shyness) for Character Education. Jurnal Ilmiah Peuradeun, 7(1), pp.125140, p. 126.

- Glasse, Cyril. 2002. Ensiklopedi Islam. Terj . Ghufran A. Mas'adi. Jakarta: Raja Grafindo Persada.

- Langgulung, Hasan. 1995. Manusia dan Pendidikan, Suatu Analisa Psikologi dan Pendidikan. Jakarta: Alhusna Zikra.

- Yunus, Mahmud. 1989. Sejarah Pendidikan Islam. Jakarta: Hidayakarya Agung.

- Nakosteen, Mehdi. 1995. Kontribusi Islam Atas Dunia Intelektual Barat: Deskripsi Analisis Abad Keemasan Islam. Terj. Joko S. Kahhar. Surabaya: Risalah Gusti.

- Nata, Abuddin. 2004. Sejarah Pendidikan Islam pada Periode Klasik dan Pertengahan. Jakarta: Raja Grafindo Persada.

- Nizar, Samsul (editor). 2009. Sejarah Pendidikan Islam - Menelusuri Jejak Sejarah Pendidikan Era Rasulullah Sampai Indonesia. Jakarta: Kencana Prenada Media Group.

- Niswah, Chairun. 2015. Pendidikan Islam pada Masa Khulafa al-Rasyidin dan Bani Umayyah. Jurnal Tadrib. Vol. 1 No. 2.

- Syalabi, A. 2000. Sejarah dan Kebudayaan Islam I, terj. Mukhtar Yahya, Jakarta: alHusna Zikra.

- Sukarno dan Ahmad Supardi. 1985. Sejarah dan Filsafat Pendidikan Islam. Bandung: Angkasa.

- Tafsir, Ahmad. 2005. Ilmu Pendidikan Dalam Perspektif Islam, Bandung : Remaja Rosda Karya

-Zuhairini, dkk. 1997. Sejarah Pendidikan Islam. Jakarta: Bumi Aksara. 